\title{
構造物境界部における角折れ時の バラスト軌道の道床横抵抗力特性
}

\author{
山本 紗穏里 1 ・中村 貴久 2 ・桃谷 尚嗣 3 早野 公敏 4 \\ 1学生会員 横浜国立大学理工学部 建築都市・環境系学科 \\ （ ○240-8501 神奈川県横浜市保土ヶ谷区常盤台79-5） \\ E-mail: yamamoto-saori-tn@ynu.jp \\ 2正会員 (公財) 鉄道総合技術研究所 軌道技術研究部（干185-8540 東京都国分寺市光町2-8-38） \\ E-mail: nakamura.takahisa.19@rtri.or.jp \\ 3正会員 (公財) 鉄道総合技術研究所 軌道技術研究部（†185-8540 東京都国分寺市光町2-8-38） \\ E-mail: momoya.yoshitsugu.29@rtri.or.jp \\ 4正会員 横浜国立大学大学院教授 都市イノベーション研究院 \\ （†240-8501 神奈川県横浜市保土ヶ谷区常盤台79-5） \\ E-mail: hayano-kimitoshi-hg@ynu.ac.jp
}

\begin{abstract}
鉄道構造物境界におけるバラスト軌道では，地震時に局所的変位が生じると道床横抵抗力が低下し，軌 道の水平安定性が損なわれる。しかし, 現場で生じる様々な条件下の道床横抵抗力特性を調べることは難 しく，いままでに蓄積された資料は乏しい，そこで本研究では局所的変位をもたらすものとして，角折れ に着目し，室内で角折れが発生できる装置を製作して模型試験を実施した．模型試験では道床横抵抗力に 折れ角の大きさや回数, 開閉状態が及ぼす影響, そして1本引き載荷試験と軌きょう引き載荷試験におけ る違いなどについて調べた.
\end{abstract}

Key Words : ballasted track, structure boundary, angular rotation, model test, lateral resistance

\section{1. はじめに}

鉄道バラスト軌道の道床横抵抗力は，水平安定性の観 点から重要である ${ }^{1)}$. ここで道床横抵抗力は道床バラス 卜内に設置されたまくらぎを横引きしたときの抵抗力で ある。

鋼製のレールは温度変化により長軸方向に伸縮しよう とするが，拘束により伸縮量に制約があるため，軸力が 増加して座屈することが懸念される2). このレールの座 屈を抑制するためには，過度な水平変位がまくらぎに生 じないように, 十分な道床横抵抗力の確保が必要である. 特に地震時には道床横抵抗力が低下し, 安定性の向上 を図る必要がある。浅沼ら ${ }^{3}$ は，軌道座屈安定解析を実 施し, 地震動の大きさ, 最終道床横抵抗力の低下の程度, 構造物の諸元によっては大きなレール横変位が生じるこ とを明らかにしている。

地震時に道床横抵抗力の低下がごの程度実際に生じる かについて, 中村ら ${ }^{4)}$ 5) は大型振動台実験を実施し, 正 弦波や実地震波を用いた加振により，道床横抵抗力の低
下率を把握している，具体的には加速度のレベル，道床 形状の変化あるいは入力波形の違いなどの観点から把握 している. 同時に，座屈防止板やバラスト止め壁による 座屈防止対策工の効果を確認している. 小林らきも, 盛 土上のバラスト軌道を対象に振動台実験を実施し，ジオ テキスタイル材料で補強した軌道構造がバラストの流失 を防止するとともに，道床横抵抗力の確保に効果がある ことを実証している.

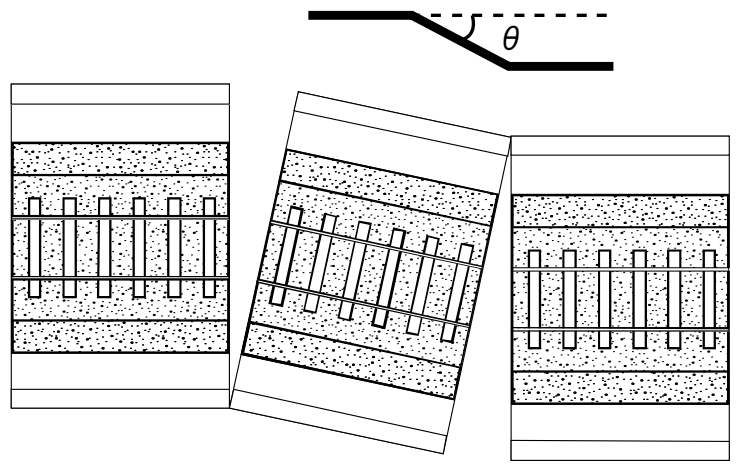

図-1 角折れの状況 
このように地震時における道床横抵抗力の低下率，そ のメカニズムおよび向上対策について精力的に研究がな されている，ところが，盛土区間と橋台区間の境，ある いは張出式RCラーメン高架橋などに見られる構造物境 界部のバラスト軌道に着目したとき，その道床横抵抗力 特性に関する知見は，以下に述べるように限定的である。

構造物境界部においては地震時に “角折れ”に代表さ れる局所的変形が生じることが知られている．図-1に角 折れの状況を示す.この局所的変形は通常の振動による 変位に加えて，不同変位をバラスト軌道にもたらすこと になり，道床横抵抗力にさらに影響を及ぼすと考えられ る. 例えば曽我部ら》は，振動変位に不同変位を加えて, 構造物境界部の道床横抵抗力をさらに低下させるモデル を提案している.

構造物境界部の角折れによりどの程度道床横抵抗力が 実際に低下寸るかについて, 藤波ら ${ }^{8}$ は3次元FEM解析を 実施している．折れ角として30/1000（境界部から軌道長 手方向距離 $10 \mathrm{~m}$ 地点において直角方向に $0.3 \mathrm{~m}$ の相対変 位）を設定し，角折れにともなうバラス卜剛性低下を考 慮する形で道床横抵抗力を推定している. 解析の結果, 構造物境界部の角折れを考慮しない場合に比較して, 道 床横抵抗力が約40\%低下することを示している.

また，佐藤ら は，実物大の軌道模型を用いて高架橋 上で角折れが生じた軌道を再現し, 道床横抵抗力を測定 している. その結果，角折れ付近のまくらぎの道床横抵 抗力は，道床が乱されていない部分と比較して $30 〜 40 \%$ ほど低下することを示している，折れ角の設定は，藤波 らクと同じく30/1000であり，折れ角の大きさ $\theta$ (図-1参 照) や繰返し回数がどのような影響を道床横抵抗力に及 ぼすかについて調べた事例は見当たらない．

以上述べたように，振動が道床横抵抗力に及ぼす影響 については詳細なデータが蓄積される一方で, 角折れが 道床横抵抗力に及ぼす影響については，実験的にも解析 的にも限定された条件下でしか調心゙られていない，これ は様々な条件下の角折れ時の道床横抵抗力特性を, 実際 の現場や実物大の実験で調べるには非常な労力や費用を 要するためと考えられる.

そこで本研究では実物の $1 / 5$ サイズの道床模型を対象 に，角折れが発生できる装置を製作し，模型試験を系統 的に実施し, 様々な条件下の角折れ時の道床横抵抗力特 性を調べた. 具体的には，折れ角の大きさや角折れ回数， 開閉の状態が道床横抵抗力に及ぼす影響を調べた。同時 にPIV (Particle Image Velocimetry)解析により, 角折れ時の 道床横抵抗力低下の要因について検討した. 最後に1本 引き載荷試験と軌きょう引き載荷試験における角折れ時 の道床横抵抗力の違いについても調べた.

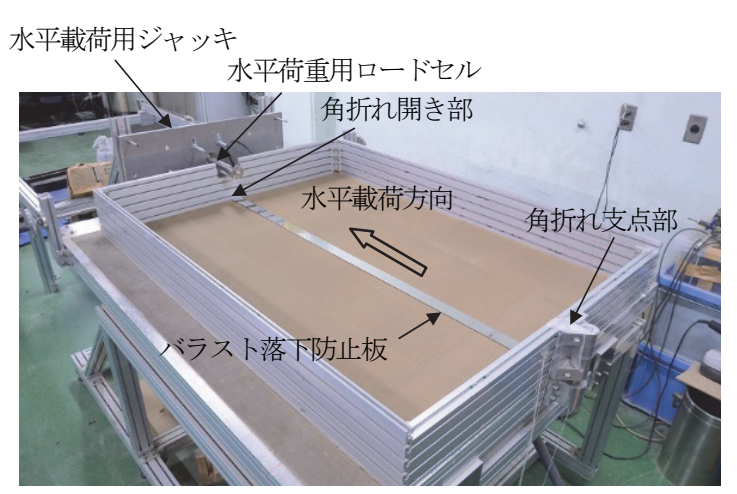

(a) 装置全体（道床模型作製前）

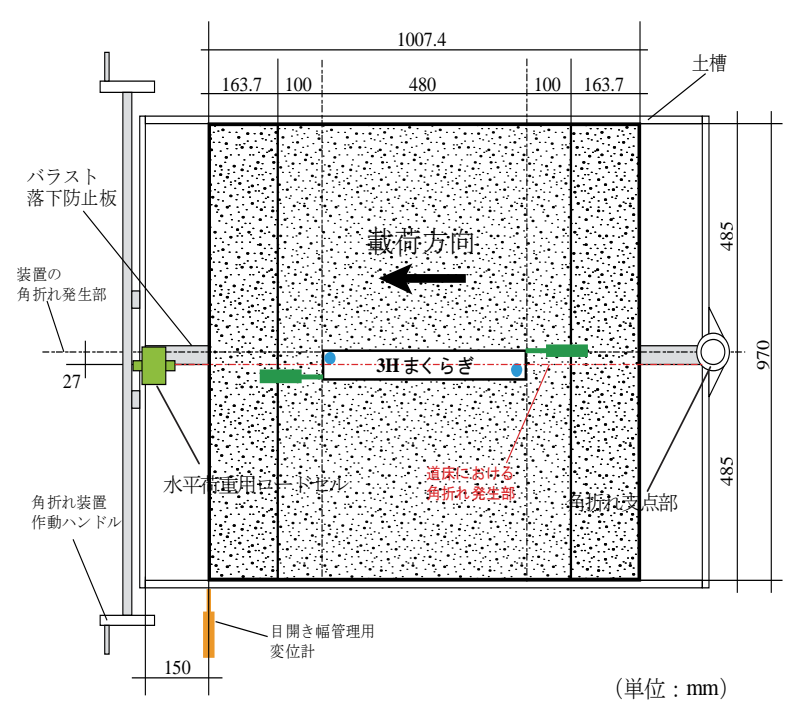

(b) 角折れ前 (道床模型作製後)

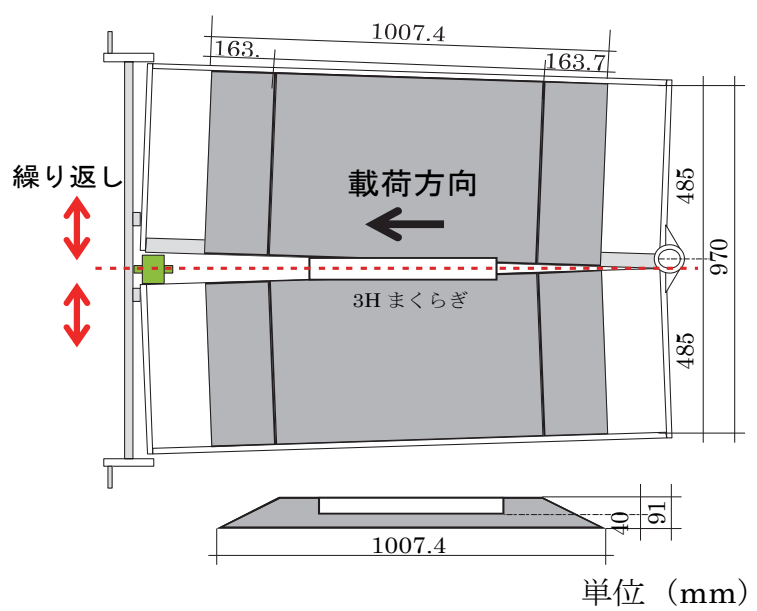

(c) 角折れ後 (道床模型作製後)

図-2 角折れ機構および水平載荷機構を具備した試験装置 (1本引き試験)

\section{2. 用いた試験装置およびバラスト，まくらぎ}

実物大軌道の $1 / 5$ サイズの道床模型を対象に，角折れ 


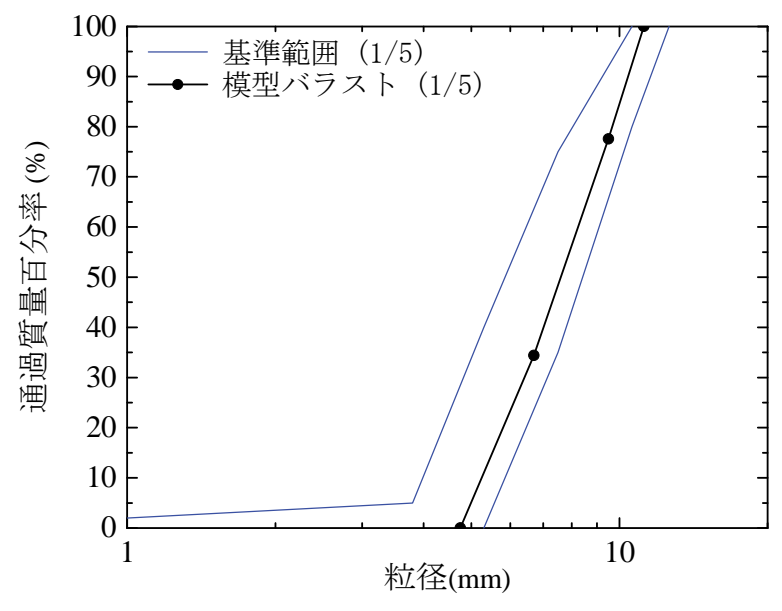

図-3 使用した砕石の粒径加積曲線

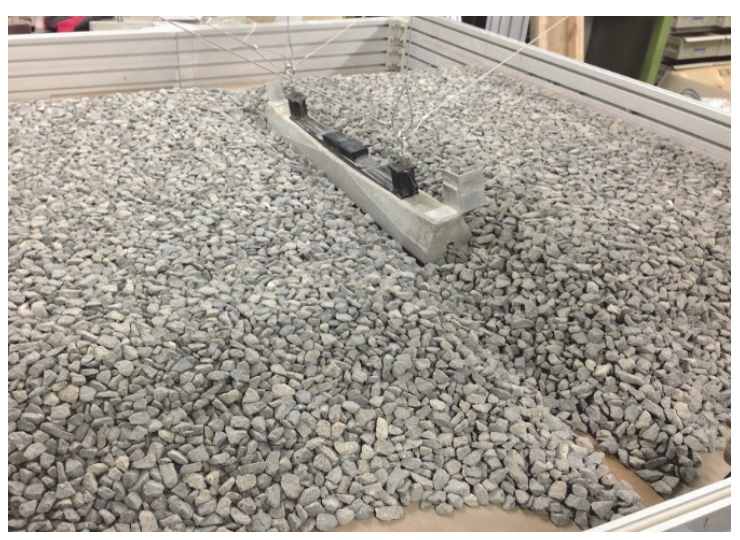

図-4 角折れが生じたときの道床

を生じさせることができ，かつまくらぎの横引きが可能 な装置を製作し，実験に使用した。使用した装置の概要 を図-2に示す，装置は主に，[1]角折れ機構が付いた土槽， [2]水平載荷機構，から構成される.

\section{(1) 角折れ機構が付いた土槽}

土槽は寸法 $1245 \mathrm{~mm} \times 970 \mathrm{~mm} \times 150 \mathrm{~mm}$ でアルミニウム製 である．土槽の中には，実際のバラストの $1 / 5$ サイズの 砕石を用いた道床模型を作製した。 用いた砕石の粒径加 積曲線を図-3に示す，同図には実物のバラストの標準粒 度に対する1/5サイズの範囲も示した。

土槽は支持台上にあり，土槽底面は中央部で2分割さ れている. 図-2に示したように一つのヒンジを中心とし て，2つに分割された部分は互いに反対方向にまわり， その結果，底面が開き角折れが発生する仕組みである。 土槽の外枠も底面と一緒に回転移動し，回転速度は，八 ンドルの手動制御で行った．なおハンドルを逆回転させ， 開いている底面を閉じる，寸なわち角折れのない状態に 戻すこともできる．角折れを生じさせたときの道床の状 況を図-4に示寸.

底面の厚さは6mmで，底面の表面にはKoike et al. ${ }^{10)}$ と同

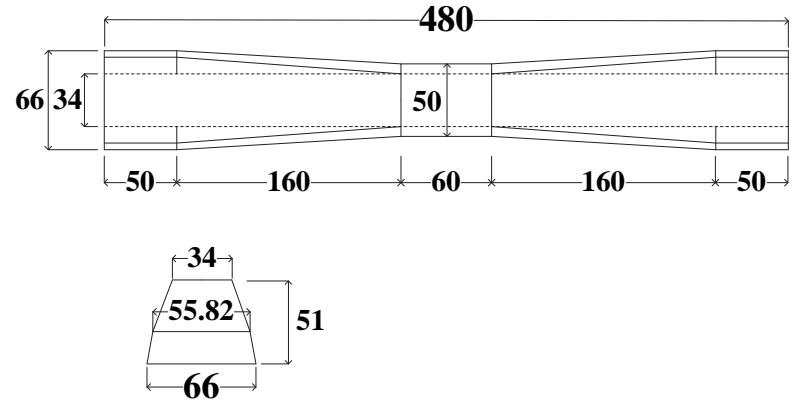

図-5用いたまくらぎの形状(3H)

様に，実際に近い摩擦条件となるようサンドペーパーを 貼り付けた．ただし，角折れが生じる境界部の底面には

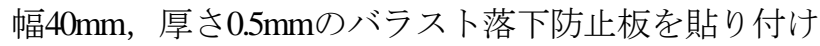
た（図-2参照）。角折れ時にこのバラスト落下防止板が 土槽底面の開口部を覆うため, 砕石が底面より下に落下 することを防ぐことができる．また道床の重さにより土 槽底面と常に密着しており，底面の開閉の際に，落下防 止板と土槽底面の間に砕石が入り込んで噛むような事態 は生じない.

\section{（2） 水平載荷機構}

水平載荷機構は, 道床横抵抗力を測定するために模型 道床内のまくらぎを横引きするものである，具体的には ロッドを介して，ジャッキ，ロードセルをまくらぎに連 結させる，そしてモーターによりジャッキを回転させる ことによりまくらぎの横引きが可能である. 横引き中の 抵抗力はロードセルによって連続的に計測される。なお， 角折れが発生した状態でも横引きが可能な機構とした.

使用したまくらぎはモルタル製で，まくらぎ寸法は実 際の $1 / 5$ である。形状は，新幹線に実際に用いられてい る3Hまくらぎのものとした．図-5に模型まくらぎ形状を 示寸.

\section{1本引き試験による道床横抵抗力特性}

\section{(1) 1本引き試験方法}

折れ角の大きさや角折れ回数などが道床横抵抗力に及 ぼす影響を調べるため，角折れを生じさせた後，まくら ぎ1本を横引きする1本引き試験を実施した（図-2および 図-4参照）。試験方法は以下の通りである.

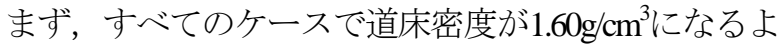
うに砕石をよく締固めて，土槽内に図-2に示寸形状の道 床を作製した，道床の作製途中では，角折れの影響を最 も受け易いと考えられる角折れ境界部の直上の道床に, まくらぎを設置した。具体的には，土槽中心線から 27mmずれた，落下防止板の端部の位置に，まくらぎの 
長軸方向と角折れ境界部が平行になるように設置した. なお，まくらぎの上面高さが道床表面と一致するように 道床を作製した.

続いて，角折れの最中および横引き時に沈下を防ぐた めに，まくらぎ上部の治具にワイヤーを通した．実際の まくらぎはレールに締結されており，角折れが生じると ぶら下がることが想定されたためである．横引き時に測 定する道床横抵抗力に, ワイヤーの張力が及ぼす影響は 無視できるほど小さいことをあらかじめ確認している. なお，治具は横引きの際にロッドと締結するために使用 するもので，その重量は，まくらぎ1本あたりで負担す るレールや締結治具の重量を考慮したものとした.

道床の作製およびまくらぎの設置が完了した後, 図-6 に示すように所定の回数の角折れを発生させた. 角折れ 時の土槽底面の回転速度は前述したように手動制御だが， なるべく一定速度（1mm/sec）になるように実施した。 そして土槽底面が開いた（角折れした）状態あるいは閉 じた（角折れしていない）状態のどちらかに保ったまま で，まくらぎとロッドを締結させ，まくらぎの横引きを 行った．横引きは，一定の載荷速度 $0.4 \mathrm{~mm} / \mathrm{min}$ でまくら

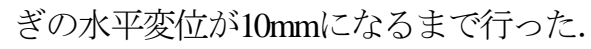

発生させた折れ角の大きさや回数は，試験ケースによ って変化させた．表-1に各試験ケースで生じさせた折れ 角の大きさ，角折れの回数および角折れの開閉状態を示

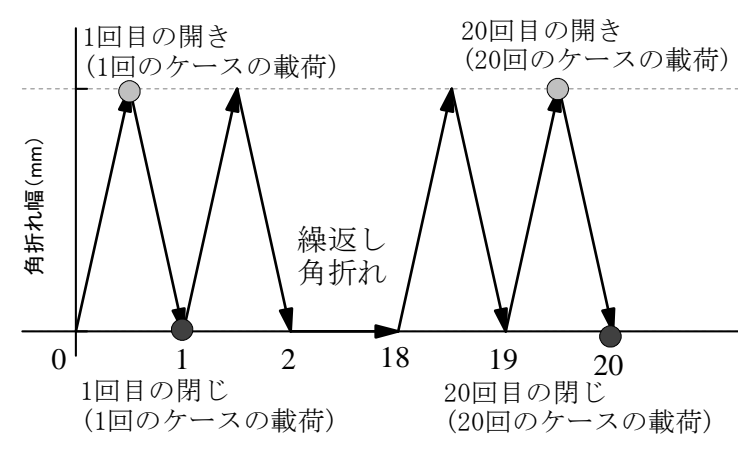

図-6 角折れの繰返しと開閉の状態

表-1 1本引き試験ケース一覧

\begin{tabular}{|c|c|c|c|}
\hline $\begin{array}{c}\text { 角折れ幅 } \\
(\mathrm{mm})\end{array}$ & 折れ角 & $\begin{array}{l}\text { 角折れ } \\
\text { 回数(回) }\end{array}$ & $\begin{array}{c}\text { 角折れ } \\
\text { 状態 }\end{array}$ \\
\hline 0 & 0 & 0 & - \\
\hline \multirow{3}{*}{5} & \multirow{3}{*}{$4.75 / 1000$} & 1 & \multirow{3}{*}{ 閉じ } \\
\hline & & 10 & \\
\hline & & 20 & \\
\hline \multirow{3}{*}{10} & \multirow{3}{*}{$9.5 / 1000$} & 1 & \multirow{3}{*}{ 閉じ } \\
\hline & & 10 & \\
\hline & & 20 & \\
\hline \multirow{5}{*}{20} & \multirow{5}{*}{ 19/1000 } & 1 & \multirow{3}{*}{ 閉じ } \\
\hline & & 10 & \\
\hline & & 20 & \\
\hline & & 1 & \multirow{2}{*}{ 開き } \\
\hline & & 20 & \\
\hline
\end{tabular}

す.同表では，折れ角の大きさを角折れ幅として表して いる. 角折れ幅は, 横引き試験における載荷側の道床法 面端部における目開き幅である（図-2の(b)参照）。角折 れ幅 $10 \mathrm{~mm}$ が折れ角の9.5/1000程度に相当する. 角折れの 回数は開閉 2 回分を正弦波1波分と考光，正弦波10波分に 相当する20回を最大值とした（図-6参照）。

同表に示寸ように，角折れ幅として5, 10, 20mmの3種 類, 角折れ回数として1, 10, 20回の3種類を設定した. 角 折れ幅が5, $10 \mathrm{~mm}$ の場合は, 角折れ回数1, 10, 20回後の閉 じた状態でそれぞれ横引きを実施し，角折れ幅が20 mm の場合は角折れ回数1, 20回目の開いた状態ならびに閉じ た状態，そして角折れ回数10回目の閉じた状態でそれぞ れ横引きを行った，また，表-1に示すように角折れを全 く生じさせない（角折れ幅が $0 \mathrm{~mm} ，$ 角折れ回数が0回）， いわゆる常時の道床の横抵抗力の測定も合わせて行った. なお，表-1に示す12ケースでそれぞれ道床を作製して横 引き試験を1回ずつ実施した，従って例えば，角折れ幅 $5 \mathrm{~mm}$ で角折れ回数が1, 10, 20回の3ケースの場合, 道床を3 回作製してそれぞれ所定の角折れ回数に達したときに横 引き試験を実施している.

\section{（2）横引きによるまくらぎの荷重～変位関係}

図-7に横引き時に得られたまくらぎの水平荷重〜水平 変位関係を示寸．角折れ幅5, 10, 20mmごとに図を分けた. また各図には，角折れを全く生じさせない場合（常時の 場合）に得られた水平荷重〜水平変位関係も合わせて示 した. なお角折れ幅が $10 \mathrm{~mm}$ で角折れ回数が1回のケース については, データロガーの不調から初期の荷重データ が欠損している.

同図を見ると，いずれの角折れ幅においても，角折れ が生じると, 常時のものより道床横抵抗力が低下してい ることが確認できる．また図-7の(c)では，角折れが閉じ た（角折れから元に戻した）状態よりも開いた（角折れ している）状態で横引きしたほうが, 道床横抵抗力がよ り低くなっている，開いた状態では，角折れによるバラ ストのゆるみや沈み込みがより顕著になる. そのため, まくらぎ底面や側面で発揮される摩擦力が小さくなり, 道床横抵抗力がより減少すると考えられる.

角折れが閉じた状態における, 横引きした際のまくら ぎの鉛直変位〜水平変位関係を図-8に示寸．鉛直変位は 載荷側のまくらぎ端部で測定したもので, 横引き直前の 状態を原点とし，まくらぎが上昇する側を正とした．同 図には角折れを全く生じさせない場合の関係も合わせて 示した.

同図をみると，角折れを与えない横引きの場合，水平 変位の増加に伴い鉛直変位が増加する. これは, まくら ぎ直下のバラストが横引き中にせん断変形し, ダイレタ ンシー特性として膨張するためである. 一方, 角折れを 
与えた場合，鉛直変位はあまり変わらないかあるいは減 少する傾向を示寸，特に角折れ幅が大きいほどまくらぎ が沈下寸る傾向が見られる. これは角折れ中に，まくら ぎは幾分上昇するが，その後の横引きでまくらぎが沈下 していることになる. 寸なわち，角折れによってまくら ぎ底面のバラスト粒子がゆるみ，正のダイレタンシー特 性が弱くなっていると考えられ, 底面の摩擦抵抗力を減 少させる要因になっていると推察される.

角折れが開いた状態ではまくらぎの姿勢が若干乱れた

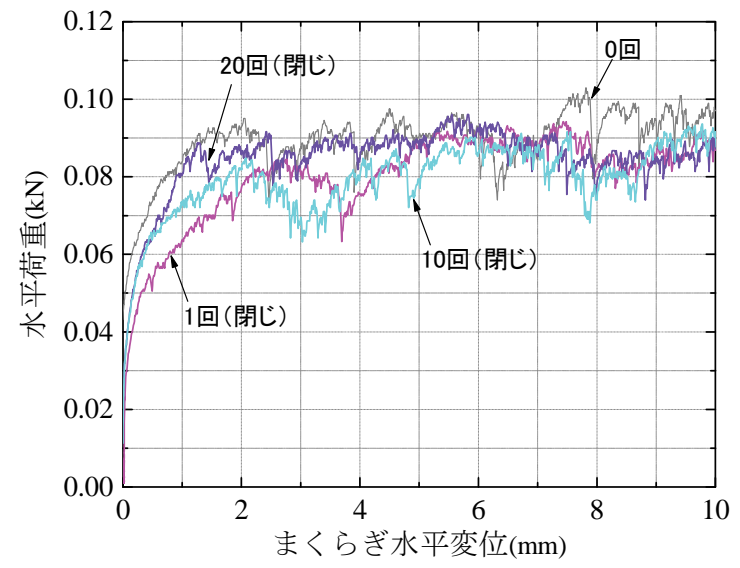

(a) 角折れ幅が $5 \mathrm{~mm}$

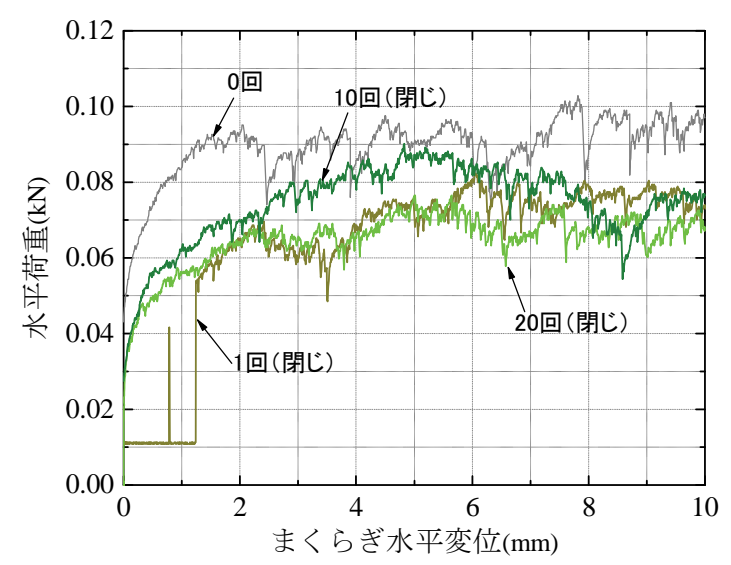

(b) 角折れ幅が $10 \mathrm{~mm}$

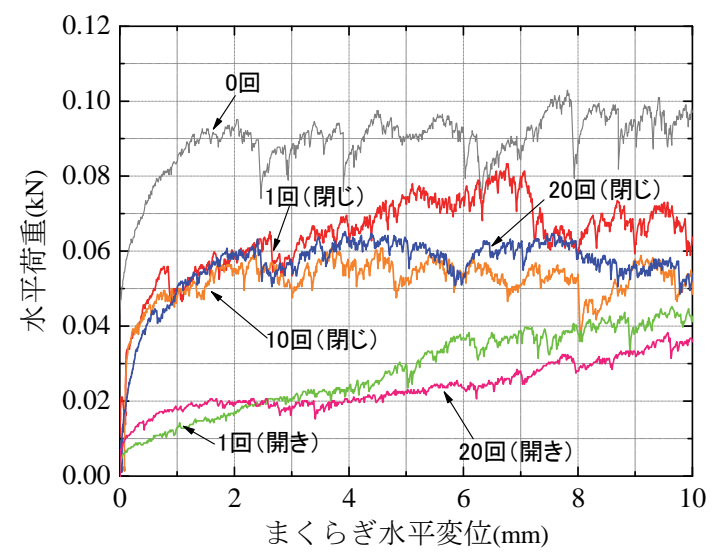

(c) 角折れ幅が $20 \mathrm{~mm}$

図-7 横引きによるまくらぎの水平荷重〜水平変位関係 （1本引き試験）
ため，鉛直変位を測定できなかったが，前述した水平荷 重〜水平変位関係から, 開いた状態のほうが角折れによ るバラストのゆるみや沈み込みがより顕著になると考え られる。

\section{(3) 角折れ幅 - 角折れ回数が最終道床横抵抗力に及ぼ す影響}

図-7に示した横引き時の水平荷重〜水平変位関係にお いて，水平変位5～10mmの関係がおおむ水水平になって いることから，この区間の平均值を最終道床横抵抗力と

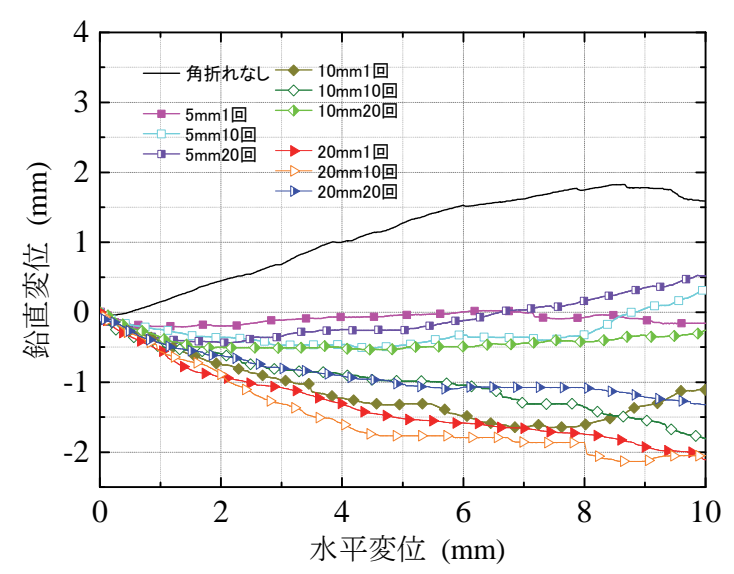

図-8＼cjkstart横引きによるまくらぎの鉛直変位〜水平変位関係 (1本引き試験)

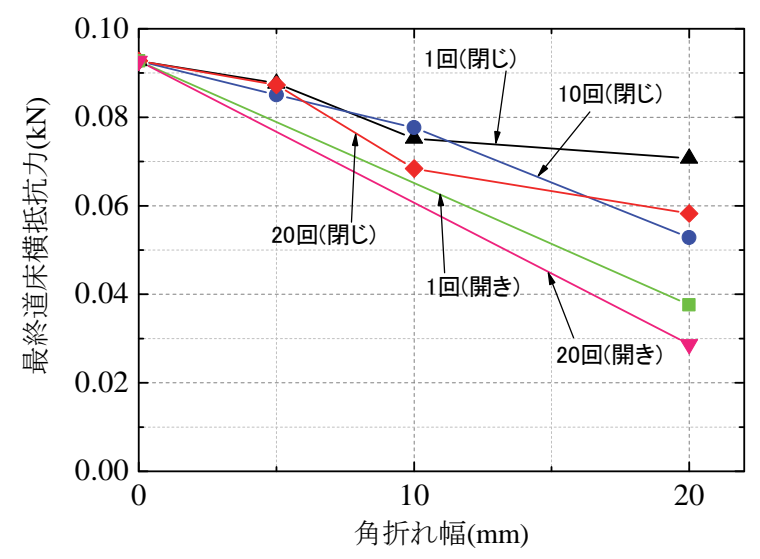

図-9 最終道床横抵抗力～角折れ幅関係

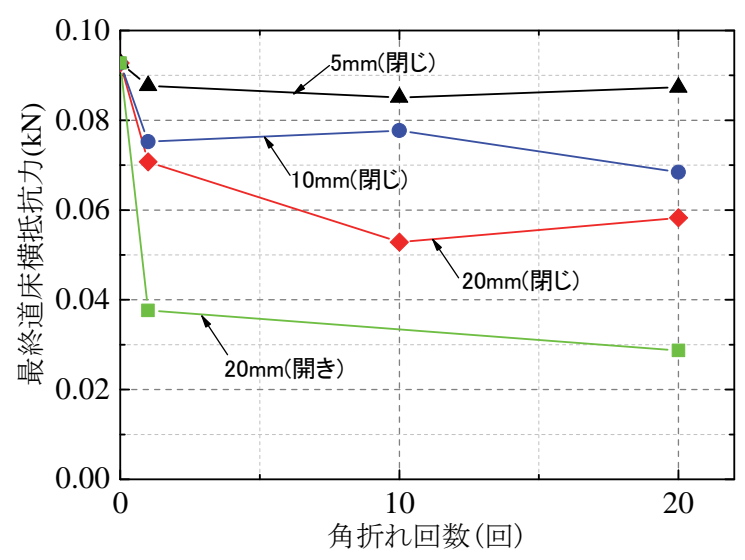

図-10 最終道床横抵抗力～角折れ回数関係 
して各ケースの值を求めた. 水平荷重の最大值ではなく, 平均值としたのは, データに変動がみられるためである.

角折れ幅と最終道床横抵抗力との関係を図-9に示寸. いずれの角折れ回数においても，角折れ幅が大きいほざ 最終道床横抵抗力が低下している.

角折れ回数と最終道床横抵抗力の関係を図-10に示す. 角折れ幅が $5 \mathrm{~mm}$ の場合は角折れ回数が1回で，角折れ幅 が10mmと20mmの場合は角折れ回数10回ほどで, 最終道 床横抵抗力の低下が収まる傾向にある. 角折れ回数が20 回の時，角折れが閉じた状態では角折れ幅5, 10, 25mmの 場合について道床横抵抗力が6\%，26\%，37\%低下してい る. 開いた状態では角折れ幅 $20 \mathrm{~mm} の$ 場合に道床横抵抗 力が69\%低下している.

\section{4. 道床横抵抗力低下の要因}

前章で示したように角折れが生じると，道床横抵抗力

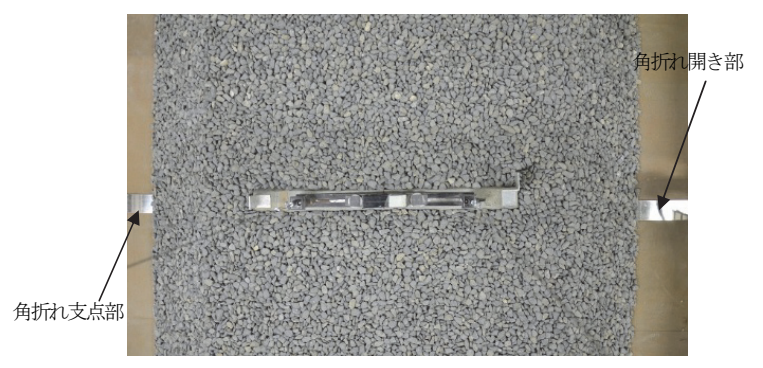

(a) 角折れ 1 回目を与える直前

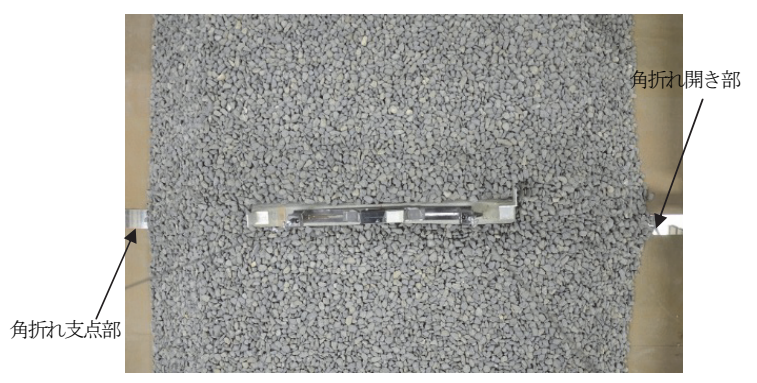

(b) 角折れ 20 回後の閉じた状態

図-11 PIV 解析に用いた画像

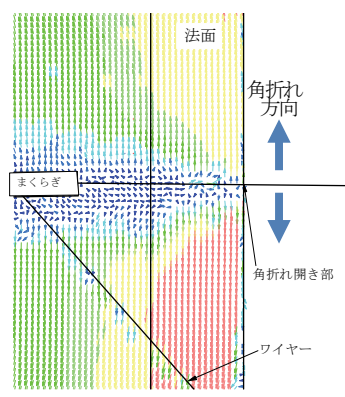

(a) 開いた時

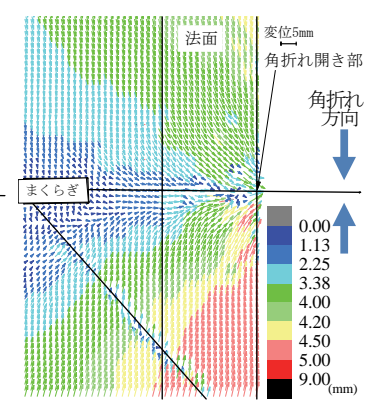

(b) 閉じた時
図-12 角折れの開閉に伴うバラストの移動
は低下寸る，低下寸る要因の一つとして，角折れによっ てまくらぎ底面のバラスト粒子がゆるみ，正のダイレタ ンシー特性が弱くなるとともに底面の摩擦抵抗力を減少 させることを前述した.

一方，まくらぎの道床横抵抗力は底面摩擦力のみなら ず，端面抵抗力や側面抵抗力によっても発揮される ${ }^{11,}$, 12) そこで，角折れが端面抵抗力や側面抵抗力に及ぼす影響 を定性的に調べるため，角折れが生じる際のバラスト粒 子の挙動をPIV解析により把握した。 具体的には表-1の 試験ケースのうち, 角折れ幅が $10 \mathrm{~mm}$ で角折れ回数が 20 回そして角折れが閉じた状態で横引きを行ったケースを 対象に，土槽上部からデジタルカメラによる撮影を行っ た.

画像撮影は，角折れを与える直前，そして1〜20回の 各回の角折れが開いた状態および角折れが閉じた状態に おいて行った. PIV解析に用いた画像の例を図-11に示寸. なお，画像は道床の上部から撮影したものであるため, 実際のバラストの挙動は3次元であるが，算出した変位 および最大せん断ひず夕などの值はすべて2次元に投影 したものである.

\section{(1) 角折れの開閉によるバラストの流出}

[1]角折れを与える直前から1回目に開いた状態に至る までのバラスト粒子の移動，[2]1回目の開いた状態から1 回目の閉じた状態に至るまでのバラスト粒子の移動を, それぞれ求めた結果を図-12に示寸，変位量を算出した 格子点の間隔は8.1mmである. なお図中の斜めの線は, 沈下を防ぐためにまくらぎ上部の治具に通したワイヤー である。

図-12の(a)では角折れが開いた時，バラスト粒子は土 槽の回転に追随し移動している。一方，図-12の(b)では 角折れが閉じた時に，まくらぎ端部から道床法尻方向に 向かってバラスト粒子が流出している. したがって, 図 -4に示したような, 角折れによるまくらぎ端部周辺の道 床流出は, 角折れが閉じた際に発生していると考えられ る. 初期状態で密に詰まったバラスト粒子は, 角折れが 開いたことによってせん断変形し体積澎張するが，その 後角折れが閉じても元の密度に戻ることができないため, 法尻方向に流出したものと考えられる.

\section{（2）角折れの繰返しに伴うまくらぎ端部道床の塑性化}

角折れを与える直前から角折れ20回目の閉じた状態に 至るまでの, 角折れの繰返しに伴うバラスト粒子の累積 変位を算出した，得られた累積変位の分布を図-13に示 す. 角折れの支点とは反対側の開き部，すなわち横引き 時の載荷側のまくらぎ端部から，八の字状にバラストが 変位している状況が認められる。

図-13の変位ベクトル分布から最大せん断ひずみ分布 


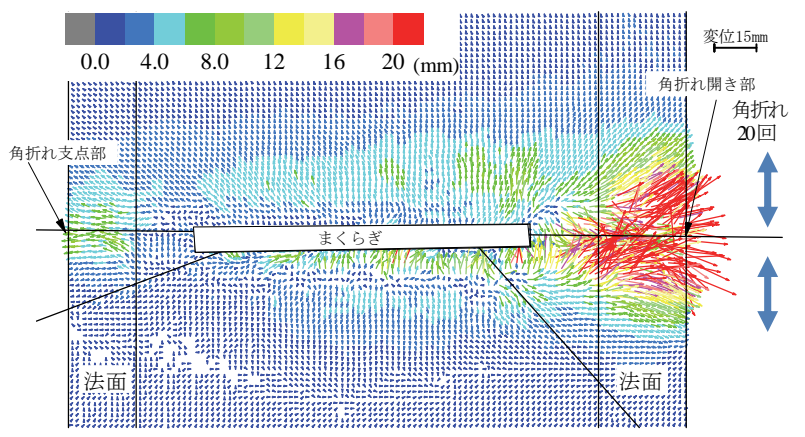

図-13 角折れの繰返しに伴うバラスト粒子の累積変位

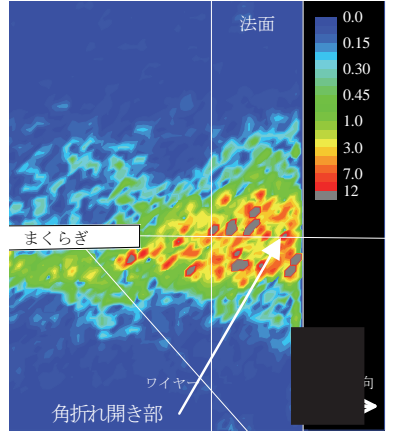

(a) 角折れ20回後の閉じた状態

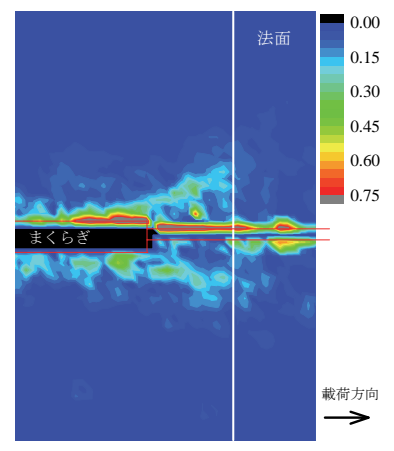

(b) 角折れなしの横引き後
図-14 まくらぎ端部付近の最大せん断ひずみ分布

を算出した．具体的には前述したように2次元の平面ひ ずみ条件を仮定し，格子点の変位から最大せん断ひずみ を求めた，得られたひずみ分布を図-14の(a)に示す．ま くらぎ長軸方向に対し -40〜40度ほどの範囲に顕著な最 大せん断ひずみが分布している．図-14の(b)には角折れ を全く生じさせない常時における道床で，まくらぎを横 引きした際に得られた最大せん断ひずみ分布 ${ }^{13)}$ を示した。

図-14の(a) と(b)を比較すると，角折れによって顕著に 塑性化する領域は，まくらぎを横引きする際に塑性化す る領域と重なっていることがわかる，すなわち，角折れ が生じた道床では，本来まくらぎが横引きされる際にバ ラストがせん断変形して破壊すべき領域がすでにせん断 破壊してしまっているため端面抵抗力が減少し，道床横 抵抗力の低下の一因となったと考えられる.

\section{（3）バラスト粒子の移動による側面土圧の減少}

図-13において，まくらぎ側面付近のバラスト粒子は まくらぎから離れる方向に移動している．横引き時の載 荷側の位置になるほど，その移動量は大きい.

まくらぎ側面のバラストの挙動を詳細に見るため，ま くらぎ長軸から $100 \mathrm{~mm}$ 程度離れた位置に着目してバラス 卜粒子の挙動を調べた，着目した道床の位置を図-15に 示寸，同図は道床模型のまくらぎ付近を上から眺めた上 面図である，着目位置は，横引き時の載荷側および非載 荷側で1点ずつ, そして両地点の中心の合計3点とした.

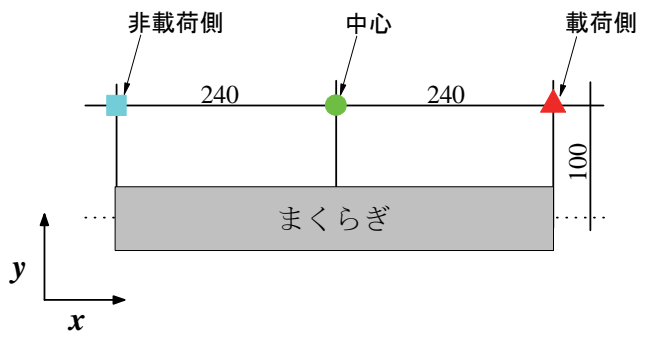

図-15 着目した道床位置（上面図）

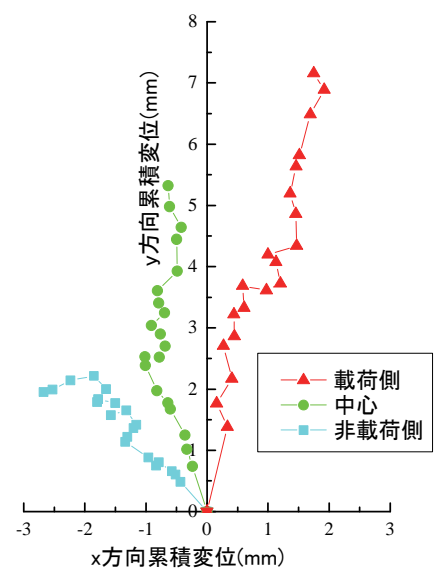

図-16 角折れの繰返しに伴うバラストの累積変位

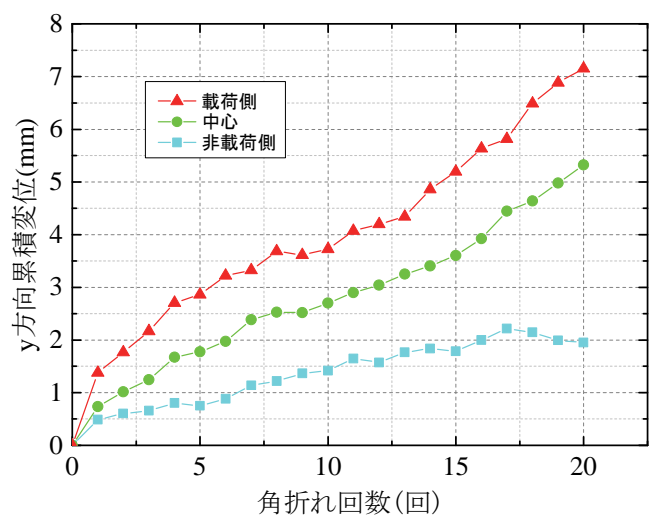

図-17 角折れ回数とバラストのy方向累積変位

同図にはxy方向の定義も示した.

角折れの繰返しに伴う，各位置でのバラストの $x, y$ 方 向の累積変位を図-16に示寸．非載荷側ではx方向の負の 向きに向かって3mmほど変位している。 これは非載荷側 の道床法尻方向に向かってバラストが移動していること を意味する，一方，載荷側では正の向きに2mm程度移動 しており，載荷側の道床法尻方向に向かって移動してい ると考えられる．まくらぎ中央付近では変位はほぼ $y$ 方 向のみである。

図-17は各位置のy方向の累積変位を，角折れの繰返し 回数に対してプロットしたものである.いずれの位置で も，y方向は正の向きに変位しており，まくらぎからバ 
ラスト粒子が離れる傾向にあることを示している．繰返 しの回数の増加に対して，変位量の収束傾向は認められ ない．角折れ1回時のy方向累積変位をまくらぎ高さ 51mmで正規化すると，1.2〜2.7\% となり，側面に働く土 圧状態が静止から主働に移行するのに十分である．最終 的には側面の露出に至り，側面抵抗力が減少し，道床横 抵抗力の低下の一因となったと考えられる.

\section{5. 軌きよう引き試験による道床横抵抗力特性}

(1) 軌きょう引き試験方法

1本引き試験は比較的試験方法が簡便であるが，実際 には複数のまくらぎがレールに締結されており，レール の剛性や隣りあうまくらぎの干渉などが考慮されない.

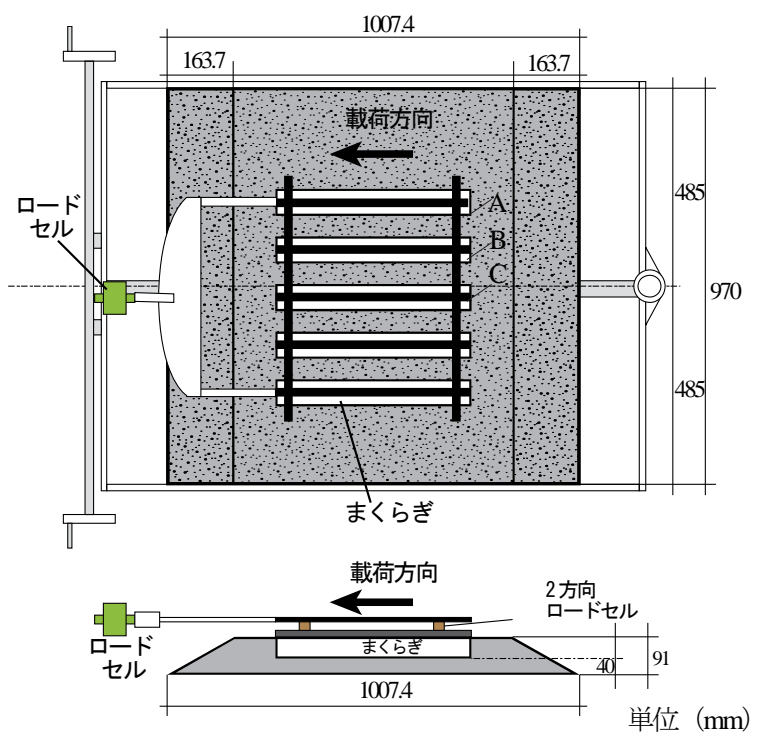

図-18＼cjkstart軌きょう引き試験概要

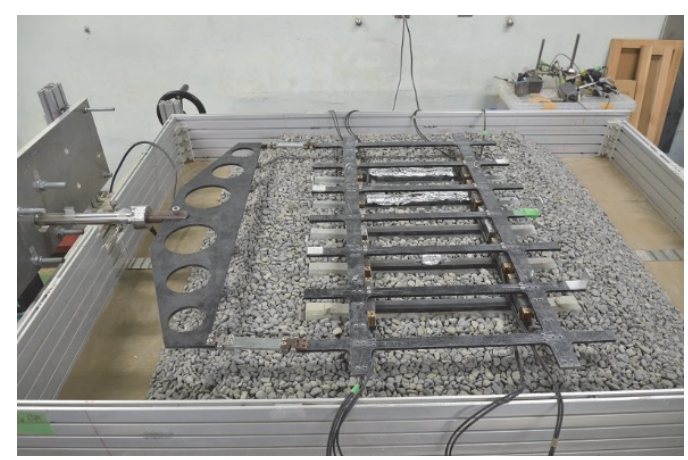

図-19＼cjkstart軌きょう引き試験の様子

表-2＼cjkstart軌きょう引き試験ケース一覧

\begin{tabular}{|c|c|c|}
\hline 角折れ幅 $[\mathrm{mm}]$ & 角折れ状態 & 回数[回] \\
\hline 0 & - & 0 \\
\hline \multirow{2}{*}{20} & \multirow{2}{*}{ 開き } & 1 \\
\cline { 3 - 3 } & & 20 \\
\hline
\end{tabular}

そこで労力を要するが，1本引き試験と同じ装置を用い て，バラスト道床内にまくらぎ5本からなる軌きょうを 設置し，1本引き試験と同様に，角折れを生じさせた後 に横引きを行った。試験の概要を図-18に，また試験の 状況を図-19に示寸．試験方法は以下の通りである.

まず，砕石を用いて道床を作製した，道床の形状や密 度は，1本引き試験のもの（図-2参照）と同じである. 道床の作製中に，3Hまくらぎを等間隔で5本設置し，同 時に剛性の高い軌きょうに各まくらぎを連結した，具体 的には図-18に示したまくらぎCの位置が，1本引き試験 におけるまくらぎのものと同じになるように設置した

（図-2の(b)参照）。まくらぎ間隔は116mmである。また 図-18に示すように，軌きょうとまくらぎの間にロード セルを設置して，まくらぎAとBに作用する水平荷重を それぞれ計測できるようにした，なお各まくらぎには口 一ドセルを二個ずつ設置し，水平荷重の算出には二個の ロードセルの值の合計值を用いた．軌きょうや取付け治 具，ロードセルなどの重量は，実際のレール荷重を考慮 してカウンターバランスを用いて調整した.

道床の作製およびまくらぎ・軌きょうの設置が完了し た後，1本引き試験と同様に所定の回数の角折れを発生 させた．続いて軌きょうの横引きを行った．剛性の高い 軌きょうにより連結されているため，横引き中には，ま くらぎ5本が同時に一緒に移動する．角折れ中の回転速 度や横引きにおける載荷速度は，それぞれ1本引き試験 と同じである。

表-2に試験ケース一覧を示寸．角折れ幅を $20 \mathrm{~mm} と し ，$ 1回あるいは20回の角折れを生じさせたあとに，開いた 状態（角折れした状態）で横引きを行った，なお，角折 れを全く生じさせない（角折れ幅が $0 \mathrm{~mm}$ ，角折れ回数が 0回の）道床についても，軌きょう引き試験を実施した．

\section{（2）横引きによるまくらぎの荷重～変位関係}

軌きょう全体の水平荷重～水平変位関係を図-20に示 す。初期の道床横抵抗力は，角折れ1回と20回ではほと

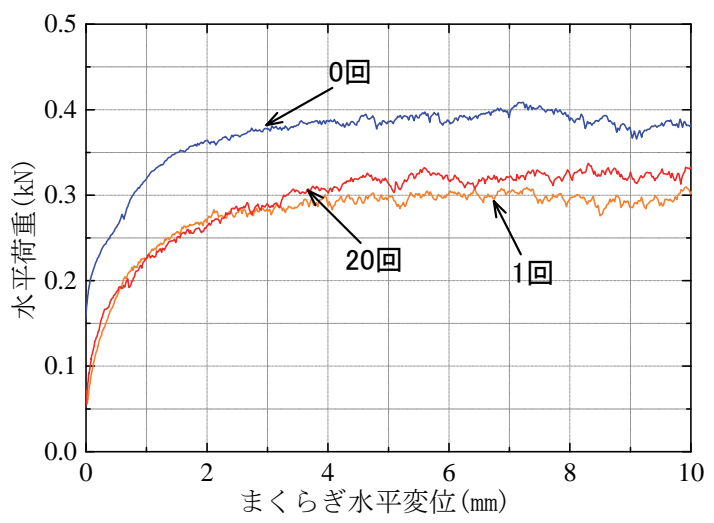

図-20 横引きによるまくらぎの水平荷重～水平変位関係

（軌きょう引き試験） 


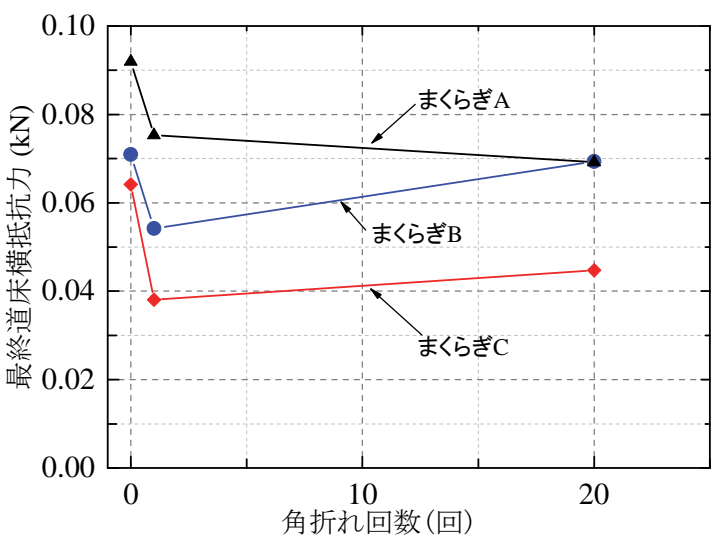

図-21 各まくらぎで負担する最終道床横抵抗力の変化

んど差が見られない．その後は角折れ1回の方が少し小 さくなっている，軌きょう全体でみると，角折れしない 状態に比べ20～25\%程度最終道床横抵抗力が低下してい る. 1本引き試験の場合，同じ角折れ幅 $20 \mathrm{~mm}$ で同じく開 いた状態で最終道床横抵抗力が 60〜 70\%程度低下してい る．1本引き試験と軌きょう引き試験それぞれの低下率 が異なる結果となっている.

\section{（3）各まくらぎにおける低下率}

前述したように1本引き試験に比べると，軌きょう引 き試験における最終道床横抵抗力の低下率が小さかった 軌きょうにおける各まくらぎに対する角折れの影響が異 なるためと考えられ，図-18のまくらぎA，B，Cそれぞ れの道床横抵抗力を整理した。 まくらぎCの道床横抵抗 力は，対称性を仮定し軌きょう全体の道床横抵抗力から 下記のように算出した。

$$
\mathrm{LR}_{\mathrm{C}}=\mathrm{LR}_{\text {全体 }}-2\left(\mathrm{LR}_{\mathrm{A}}+\mathrm{LR}_{\mathrm{B}}\right)
$$

ここで $\mathrm{LR}_{\mathrm{A}} ， \mathrm{LR}_{\mathrm{B}} ， \mathrm{LR}_{\mathrm{C}}$ はまくらぎA，B，Cそれぞれの道 床横抵抗力を，LR全体は軌きょう全体の道床横抵抗力を 表す.

図-21に各まくらぎの最終道床横抵抗力と角折れ回数 の関係を示す．同図で角折れが発生しない状態で，すで に各まくらぎが分担する道床横抵抗力が異なるが，これ は群杭効果や境界条件の影響として知られる。 まくらぎ Cの最終道床横抵抗力は群杭効果の影響を特に受けるた め小さい.

同図で角折れの影響を見るとまくらぎBの20回目の傾 向がやや異なるが，角折れによる低下はまくらぎCの場 合20～40\%程度であり，まくらぎA，Bの場合5～25\%程 度である．設置位置が同じであるまくらぎCの場合でも， 1本引きの角折れによる低下率60～70\%に比べて小さい

角折れが生じると，まくらぎ端面が露出するほどバラ ストが流出し，1本引きの場合には特に側面も露出寸る。 しかし軌きょう引きの場合，隣接するまくらぎによりバ ラストが拘束されているため，それほど側面が露出しな
い. 加えてもともと群杭効果によりまくらぎ端部の抵抗 力の全体に対寸る貢献が相対的に小さいため, 軌きょう 引きのほうが1本引きより低下率が少ないと考えられる。

\section{6. まとめ}

現場で生じる様々な条件下の角折れ時の道床横抵抗力 特性を調べることは難しく，いままでに蓄積された資料 は乏しい，そこで本研究では水平角折れに着目し，角折 れが発生できる装置を製作し，模型試験を実施した．以 下に得られた知見を示す。

1）まくらぎ1本を横引きする1本引き試験の結果，角折 れが生じると，常時のものより道床横抵抗力が低下 した. 角折れが閉じた（角折れから元に戻した）状 態よりも開いた（角折れしている）状態のほうが, 道床横抵抗力がより低下した。

2) 角折れ幅が大きいほど最終道床横抵抗力が低下寸る 一方で，角折れ回数の増加にともなう道床横抵抗力 の減少は, 1 10回程度の繰返し回数で収束する傾 向にある。

3） PIV解析などを実施した結果，角折れにより道床横 抵抗力が低下寸る要因として，まくらぎ下部の道床 のゆるみ，まくらぎ側面に作用する土圧の低下およ び道床流出に伴うまくらぎ端部の道床の塑性化など が考えれる.

4） 1本引き試験では，20mmの角折れが生じると角折れ 部直上で道床横抵抗力が60～70\%ほど低下したのに 対し，軌きょう引き試験では，軌きょう全体の道床 横抵抗力は，20～25\%ほどしか低下しない.

5）軌きょうにおける各まくらぎの低下率を調べたとこ ろ，角折れ部直上のまくらぎで角折れによる低下率 は20～40\%程度であり，やはり1本引きより低下率 が小さい，その理由として拘束効果や群杭効果の影 響が考えられる.

\section{7. おわりに}

今後の研究として実規模レベルの検証が望まれるが, 実物大実験の実施には大変な労力がかかる。そのため, FEMなどの解析の適用が期待され，適用の際には，本研 究で得られた知見をもとに，解析精度の検証を行うこと が可能になると考えられる。

\section{参考文献}

1) 片岡宏夫：ロングレールの座屈防止, RRR, Vol. 65, No. 9, pp. 8-11, 2008.

2) 柳川秀明：最新の鉄道設計技術 ロングレールの適用 範囲拡大時の設計法，RRR, Vol. 63, No. 2, pp. 18-21, 
2006.

3）浅沼潔，関根悦夫，片岡宏夫，曽我部正道，後藤恵 一，徳永宗正 : 鉄道力学 バラスト軌道の地震時変形 挙動，鉄道総研報告，Vol. 25, No. 6, pp. 47-52, 2011.

4) 中村貴久, 関根悦夫, 白江雄介 : 大型振動台試験に よるバラスト軌道の耐震性能評価，鉄道総研報告， Vol. 24, No. 12, pp. 23-28, 2010.

5) 中村貴久, 桃谷尚嗣, 早野公敏, 小川隆太 : 地震時 におけるバラスト軌道の道床横抵抗力特性, 土木学 会論文集 E1 (舗装工学) , Vol. 70, No. 3, pp. I_79I_86, 2015.

6) 小林幹人, 関雅樹, 渡邊康人, 可知隆, 古関潤一： ジオテキスタイル材料で補強したバラスト軌道構造 の振動台試験，ジオシンセティックス論文集，Vol. 23, No. 0, pp. 215-222, 2008.

7) 曽我部正道, 浅沼潔, 桃谷尚嗣, 中村貴久: 構造物 境界における有道床軌道の地震時座屈挙動とそのフ ラジリティ曲線, 鉄道総研報告, Vol. 28, No. 12, pp. 53-58, 2014.

8) 藤波潔, 大野和巳，関根悦夫，中村貴久：地震動を 受けた構造物境界部バラスト軌道の道床横抵抗力に 関する FEM 解析, 土木学会第 66 回年次学術講演会 講演集, IV-158, pp. 315-316, 2011.
9) 佐藤吉彦, 三浦重, 高井秀之, 長沢孝哉 : 高架橋の 水平目違いおよび水平角折れに対する軌道の変形特 性試験，鉄道技術研究所速報，No. A-85-61, pp. 1-77, 1985.

10) Koike, Y., Nakamura, T., Hayano, K. and Momoya, Y. : Numerical method for evaluating the lateral resistance of sleepers in ballasted tracks, Soils and Foundations, Vol. 54, Issue 3, pp. 502-514, 2014.

11）市川拓真，早野公敏，中村貴久，桃谷尚嗣，小池陽 平: 極限釣り合い法を用いた鉄道バラスト軌道の道 床横抵抗力の推定，土木学会論文集 E1 (舗装工学), Vol. 70, No. 3, pp. I_71-I_77, 2014.

12) Le Pen, L. M. and Powrie, W. : Contribution of base, crib, and shoulder ballast to the lateral sliding resistance of railway track: a geotechnical perspective, Proceedings of the Institution of Mechanical Engineers, Part F, Journal of Rail and Rapid Transit, Vol. 225, No. 2, pp. 113-128, 2012.

13) 山本紗穏里, 中村貴久, 桃谷尚嗣, 早野公敏, 市川 拓真 : 横抵抗力試験におけるバラスト軌道道床の変 形挙動に関する PIV 解析, 第 11 回地盤工学会関東支 部発表会講演集(GeoKanto2014), pp. 216-219, 2014.

(2015. 4. 2 受付)

\title{
LATERAL RESISTANCE CHARACTERISTICS OF BALLASTED TRACKS SUBJECTED TO ANGULAR FOLDING AT STRUCTURE BOUNDARIES
}

\author{
Saori YAMAMOTO, Takahisa NAKAMURA, Yoshitsugu MOMOYA \\ and Kimitoshi HAYANO
}

When earthquakes induce local displacements on ballasted tracks at structure boundaries, the lateral resistance decreases and the lateral stability becomes lower. However it is difficult to examine the lateral resistance characteristics under various conditions occurring in the field, so that our knowledge related to this issue have not been accumulated. Therefore, angular folding which is one of the phenomena causing local displacements is focused in this study. After an apparatus which could generate angular folding was newly developed, a series of model tests were conducted. From the model tests, effects of folding angles, the repetition numbers, and the opening or closing status on the lateral resistance were investigated. In addition, differences between lateral resistances from single-sleeper pullout tests and those from trackpanel pullout tests were also studied. 